\title{
体内動態を考慮する新たな毒性評価系の開発
}

\author{
小森喜久夫, ${ }^{a}$ 名田 順, ${ }^{a}$ 宮島翔太郎, ${ }^{a}$ 小野芳朗, ${ }^{b}$ 立間 $\quad$ 徹, ${ }^{a}$ 酒井康行 $*, a, c$
}

\section{Development of New Cytoxicity Testing Systems that Include Toxicokinetic Processes}

\author{
Kikuo Komori, ${ }^{a}$ Jun NADA, ${ }^{a}$ Shotaro MiYaJima, ${ }^{a}$ Yoshiro Ono, ${ }^{b}$ \\ Tetsu TATSUMA, ${ }^{a}$ and Yasuyuki SAKAI ${ }^{*, a, c}$ \\ anstitute of Industrial Science, University of Tokyo, 4-6-1 Komaba, Meguro-ku, Tokyo 153-8505, Japan, \\ ${ }^{b}$ Faculty of Environmental Science and Technology, University of Okayama, 3-1-1 Tsushimanaka, \\ Okayama City 700-8530, Japan, and ${ }^{c}$ Center for Disease Biology and Integrative Medicine, \\ University of Tokyo, 7-3-1 Hongo, Bunkyo-ku, Tokyo 113-0033, Japan
}

(Received August 1, 2007)

\begin{abstract}
Conventional in vitro cytotoxicity tests usually do not include toxicokinetic processes that affect final toxicity in the entire body. To overcome this limitation, we have been developing several types of new toxicity test systems and applying them to evaluate hazardous chemicals or environmental samples. In this review, we described two of these new systems; one is a batch-type gas exposure system based on air-liquid interface culture of lung epithelial cells, and the other is a simple double-layered coculture system incorporating permeation and biotransformation processes occurring in the small intestine. In addition, we introduce our latest approach toward further miniaturization of existing tests, that is, determination of minimum cell number necessary for obtaining physiologically-relevant tissue responses.
\end{abstract}

Key words_ cytotoxicity test; toxicokinetic; inhalation toxicity; oral toxicity; miniaturization

\section{1. はじめに}

培養細胞を用いる in vitro 毒性評価系は，各種目 的のための動物実験代替法として，その一層の利用 が期待されている．従来の一般的な in vitro 評価系 では, マイクロウェルプレートなどに播種された標 的細胞に種々の化学種を曝露し, その細胞から得ら れる応答から毒性を決定する。このような一般的な 評価系では，例えば肝での代謝を再現するために， 目的に応じて肝ホモジネートを添加するまでは行わ れることがあるものの，より一般的な動態プロセス 一肺や小腸からの吸収率や代謝, 臓器間の分配, 排 泄など一は評価結果に考慮されない。

筆者らは，日々実際に体内に摂取される大気・飲 食物からのリスクを簡便かつ迅速に評価することを

${ }^{a}$ 東京大学生産技術研究所 ( $\bar{~} 153-8505$ 東京都目黒区 駒場 4-6-1), $b$ 岡山大学環境理工学部環境デザイン工 学科（干700-8530 岡山市津島中 3-1-1), $c$ 東京大学医 学系研究科疾患生命工学センター（テ113-0033 東京都 文京区本郷 7-3-1)

*e-mail: sakaiyas@iis.u-tokyo.ac.jp 本総説は, 日本薬学会第 127 年会シンポジウムS45 で 発表したものを中心に記述したものである.
想定して，個体での曝露プロセスや体内動態プロセ スをできる限り模倣した in vitro 評価系を構築し, そこに種々の化学種を曝露したときの応答を観察し てきた。本稿では, 体外の物質が最初に曝露される 肺と小腸に着目して, 次の 2 種類の評価系を開発し た. 1 つは, 気液界面培養された肺上皮細胞へのガ ス状試料の直接曝露による毒性評価系，もう 1 つ は，小腸の吸収及び代謝プロセスを考慮する簡便な 二層培養法に基づく評価系である。これらの新規評 価系は, 既存の培養器を活用したものであり, 今後 は格段のマイクロ化・ハイスループット化が望まれ る.このための基礎検討として, 臟器と同様の生理 学的な応答を得るために必要な最小の細胞集団（ミ 二組織・臟器）の把握に関する研究の結果を紹介す る.

\section{2. 肺上皮気液界面培養モデルとガス状物質曝露} デバイス

呼吸器官は，ガス交換と同時に，同じく大気中に 存在する化学物質に曝露されたり，それを血液中に 取り込んだりする. 気体状の化学物質の呼吸器官へ の直接曝露による影響を評価するには，半透膜上に 
培養された肺上皮細胞に，上側から空気を接触さ せ，下側からのみ培養液を供給する気液界面培養 法1)に基づく in vitro 肺臓器モデルを用いるのが適 している. ${ }^{2)}$ そこで筆者らは，肺気道のモデル細胞 であるヒト肺気道がん由来の Calu-3，及び肺胞上 皮のモデル細胞であるヒト肺胞がん由来の A549 を 用いて，肺モデルを構築した。 また，その肺モデル に，ガス状の化学物質や実環境ガスなどを曝露する ための小型バッチ式システムを開発し，その評価を 行った.

まず，in vivo 様の構造をとる肺モデルを構築す るために, 市販の半透膜型培養器（カルチャーイン サート）にCAlu-3 又は A549 を播種し，気液界面 培養を行った（Fig. 1(A))。 その間，細胞接着に伴 うタイトジャンクションを反映する経上皮電気抵抗 (Trans-epithelium electrical resistance; TEER) 值を 測定したところ，培養時間に伴ってその値が上昇 し，一定になった。最終的に，Calu-3 は重層の膜， A549 は単層の膜が得られた。つまり, 用いた 2 種 類の細胞はそれぞれの由来部位である気管支と肺胞

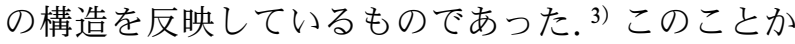
ら両細胞について，カルチャーインサートの上側を 空気と触れる体外側，下側を血液などの体内側とみ なすことができると考えられた。 また，in vivoの 肺気道や肺胞上皮は，ミクロにはこれらの組織から 分泌されるリン脂質のジパルミトイルフォスファチ ジルコリンなどの界面活性剤様物質の液層（約 10 $\mu \mathrm{m} ）$ によって被覆されており，このような状況も 気液界面培養法にてある程度再現できることが知ら れている. ${ }^{4,5}$ 本研究で構築した細胞膜の TEER が 最終的に一定值を示したことから，界面活性剂様物 質がある程度，分泌されているものと推測される.

次に, 実際にガス状物質の毒性評価を行った。気 液界面培養法を利用した従来のガス試料の毒性評価 法は，ガス等の排出源に組み込まれたフロー系であ り,これは排出源のガス評価に特化したものであ る.6)筆者らは，ガスバッグ等で，ヒトが実際に曝 露される大気試料を様々な場所から採取し，多数の 試料を簡便に評価する利用法を念頭におき，気液界 面培養された Calu-3 及び A549 を設置できる，Fig. 2 のようなガラス製のバッチ式ガス曝露装置を開発 した。そのガス曝露装置に，揮発性又は気体のモデ ル化学物質を曝露したときの細胞生存性試験を行っ

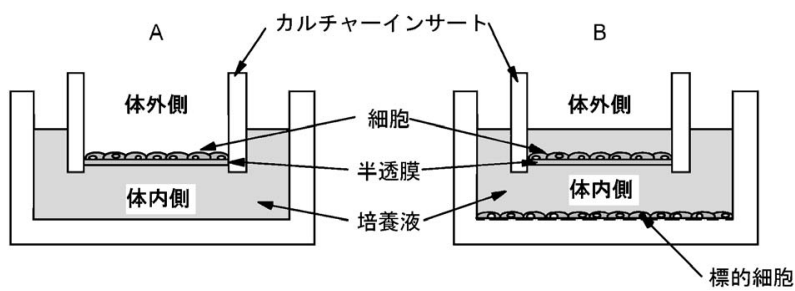

Fig. 1. Schematic Diagram of (A) Air-liquid Interface Culture System Using A549 and (B) Ddouble-layered Coculture System Using Caco-2 and Target Cells

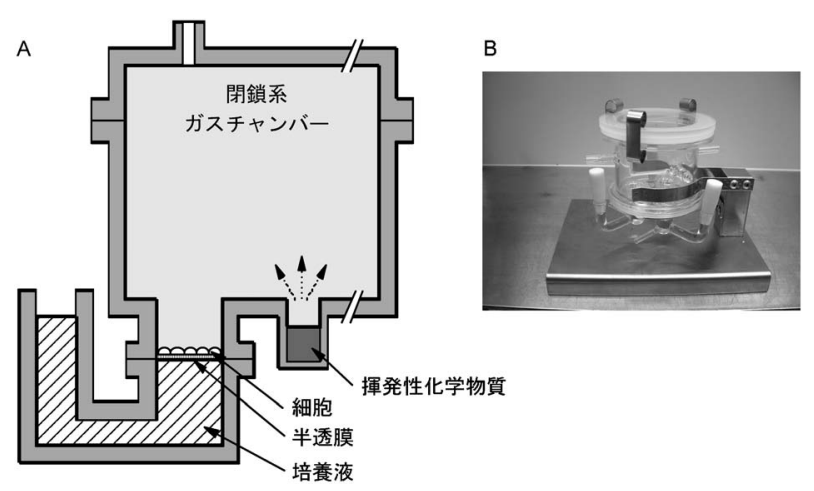

Fig. 2. (A) Image and (B) Photograph of the Gas Exposure System

た。ベンゼンやアセトン，トリクロロエチレンなど の揮発性有機物質を Calu-3 及び A549に曝露した ところ，それぞれの細胞の死滅が観察された。これ は，上記の揮発性有機物質によって，細胞膜が破壊 されることにより，細胞が壞死したものと推測され る. ${ }^{7)}$ 上記の揮発性有機物質の Calu-3 と A549 に対 する毒性を比較したところ，Calu-3に比べて， A549 は 10-100 分の 1 の濃度で死滅していた. ${ }^{8)} こ$ のときの濃度は，マウスやラットなどの動物実験で の急性毒性発現濃度とほぼ一致していた。このこと から，もちろん開発した系では肺上皮のみへの障害 しか観測できないが，少なくも動物を用いる急性の 吸入毒性試験の一部に代替できるものと考えてい る. 揮発性の有機物質以外にも，気体の無機物質の 毒性も調べた。ここでは，焼却炉等から主に排出さ れる二酸化窒素 $\left(\mathrm{NO}_{2}\right)$ や二酸化硫黄 $\left(\mathrm{SO}_{2}\right)$ ，一 酸化炭素（CO）を用いた． $\mathrm{NO}_{2}$ 又は $\mathrm{SO}_{2}$ ガスを A549 細胞が設置されたガス曝露装置に導入したと ころ，有機性ガスの場合と同様に，ラットでの急性 毒性発現濃度とほぼ同等，若しくはそれ以下の值が 得られた。これは，揮発性有機物質の場合と同様に， 
$\mathrm{NO}_{2}$ や $\mathrm{SO}_{2}$ が細胞膜に損傷を与えているものと推 測される。一方，CO（3000-100000 ppm）を曝露 した場合，細胞はほとんど死滅しなかった。生体で の $\mathrm{CO}$ に対する毒性の原因は一般的に，血液中のへ モグロビンに CO が結合することに基づく体内の酸 素不足によるものであり, in vitro 評価系では直接 的に細胞に障害を与えないことは妥当であった。い ずれにしても，本システムを用いることにより，肺 に直接損傷を与えるガスの急性毒性を見積もること は可能であった。

本ガス曝露システムを用いて，実際に人が暮らし ている大気環境中の気体（環境ガス）や，最近問題 視されているディーゼルエンジンから排出される粒 子（Diesel Exhausted Particles; DEP）の毒性を調べ た. 前者では, 建築廃材の焼却ガス，プラスチック ゴミの焼却ガス，灯油の燃焼ガス，ガソリン自動車 排ガス，国道 1 号線道路脇ガス，タバコの煙につい て調べたところ，タバコの煙では中程度の急性毒性 が観測されたが，それ以外のガスではごくわずかな 毒性が示されたに留まった. ${ }^{9)}$ 後者の DEP では, その粒子を気液界面培養された A549 細胞層表面に 直接曝露し，48 時間培養したところ，曝露濃度 （単位細胞層面積当たりの DEP 質量）の増加に伴 って，A549 の死滅が観察された。 ${ }^{10-12)}$ DEP 表面に は一般的に，100 種類以上の有機分子が吸着してい ることが知られており，その一部は，発がん，13) 気 管支炎，ぜんそく，アレルギ一反応の悪化などの肺 のみの直接的悪影響14)のほか，体内に取り込まれた のちに，生殖異常15)などの間接的悪影響を及ぼすこ とが知られている。 DEP 表面からそれら吸着物を 有機溶媒で溶出除去したものを同様に曝露した場合 では，毒性が検出されなかったことから，ここで は，肺に直接悪影響を及ぼす有機分子が DEP 表面 から脱離し，それらがA549 に損傷を与えたものと 推測される16).

上記の検討結果から，開発したガス曝露装置は, 肺を標的臓器とするようなガス状物質の急性毒性の ための肺モデルとして十分に役立つものと推測され る。しかしながら本システムを用いたガスの毒性評 価では，細胞の生存率を指標とした場合には，少な くとも 24 時間のガス曝露を必要とする．作業現場 の大気環境を調べたり，プラントからの排ガス毒性 を把握したのちにその結果をプラントの運転条件に
すぐに活かしたり，といつた実際の適用を想定する と，より短時間でガスの毒性を評価できるシステム が望まれる，筆者らは最近，極めて短時間でガス状 試料の毒性を評価するために，水系試料の高感度迅 速毒性検出法に利用されてきた発光性細菌を用いる ことで, 約 15 分のガス曝露で動物実験の急性毒性 発現濃度よりも 1-2 桁ほど，高感度に毒性を検出可 能なシステムを開発しつつある. ${ }^{9)}$ なお，本システ ムは哺乳類細胞を用いておらず，本稿の趣旨と異な るため, 詳細は割愛させて頂く.

\section{3. 小腸モデルと標的臓器モデルの複合培養系}

消化器官は，摂取された食物を消化し，栄養素を 吸収する機能を持つ。筆者らは，経口的に体内に取 り込まれた物質が, 消化器官での吸収過程を経て, 体内に及ぼす影響を評価するために，化学物質を直 接的に標的細胞に負荷する評価系に, in vitro 消化 器官モデルを組み込んだ，吸収率を考慮した複合評 価系を提案している（Fig. 1(B) ) 17)。本項では，in vitro 消化器官モデルによる吸収過程を考慮した複 合培養評価系について述べる.

化学物質の吸収透過を, in vitro で評価できる消 化器官モデルを構築するために，ヒト大腸がん由来 細胞 Caco-2 を利用した。この細胞は，新規医薬品 の吸収効果を調べるための基礎ツールとして薬学分 野で広く利用されている。この細胞を，肺モデルで 用いたものと同じカルチャーインサート上で培養す ると，比較的均一な細胞層を形成することが知られ ており，カルチャーインサートの上側を内腔側（体 外側），下側を基底膜側（体内側）とする in vitro 小腸モデルとみなすことができる（Fig. 1(B))．In vivo 小腸上皮と比較して，形成した Caco-2 膜の細 胞間結合は密であるため，親水性化学物質の透過を 過小評価するという欠点を持つものの，親油性化学 物質の透過はヒ卜小腸吸収率と相関性が高いことが 知られている. ${ }^{18)}$ まず，Caco-2 層を介した種々の 物質透過を 3 日まで検討した。 その結果，既に多数 報告されているように，化学物質を添加直後の膜透 過係数は人体での吸収率と相関し，平衡時の濃度も 内腔側と基底膜側は異なったものとなって長時間維 持された。この理由は，人体に望ましくない化学物 質を内腔側に逆輸送する極性輸送が起こっているた めである，と推測される。いずれにしても，ここで 決定された in vitro 吸収率は，それぞれの化学物質 
の in vivo ヒト吸収率と良好な関係を示したことか ら，Caco-2 の下層で標的細胞を培養することで, 腸管吸収率の補正を行つた曝露が可能であることが 明らかとなった。ささらに, Caco-2 層の下側から逆 方向の物質透過実験の結果と併せて解析すると, ${ }^{19)}$ ぞの物質についても Caco-2 の下側（基底膜側）か ら上側（内腔側）への能動的輸送の存在が示され， 膜の上下で濃度差を保ったまま平衡に達する現象が 理解できた. ${ }^{17)}$

次に, 基底膜側に標的細胞としてヒト正常 2 倍体 線維芽細胞 TIG-1 を設置し，人体の吸収率の異な る数種の化学物質を内腔側から Caco-2 に添加し,

TIG-1 への増殖阻害を指標とした毒性評価を行った.

Caco-2 と TIG-1 を組み合わせた複合培養系では, 小腸での代謝や極性輸送を引き起こさない化学物質 の $50 \%$ 増殖阻害濃度 $\mathrm{ED}_{50}$ が，TIG-1 単一培養時に 比べて, 大きく高濃度側にシフトし，その違いの程 度は上記の in vitro 吸収率の違いを反映してい た. ${ }^{17)}$

一方, ある種の化学物質については, 内腔側と基 底膜側に分配された化学物質の総量と初期添加量と のマスバランスが取れないという現象が観察され た。これは，小腸膜での代謝や極性輸送といつた生 物学的現象が関与している可能性があった。この点 をさらに検討するため，小腸や肝臓のチトクローム P450 1A1/2 (CYP 1A1/2) を中心とする解毒メカニ ズムによって代謝活性化を受け初めて強い毒性が現 れるベンゾ $[\mathrm{a}]$ ピレン（BaP） をモデル化学物質 として，同様の検討を行った。 ${ }^{20)}$ 基底膜側には肝モ デル細胞である Hep G2 を設置し, 両組織の in vivo 高代謝機能を模倣するため, Caco-2 と Hep G2 の両細胞にあらかじめ 3- メチルコラントレンで CYP 1A1/2 を誘導した。このとき, Caco-2の CYP 1A1/2 による代謝活性能は, Hep G2 のもの とほぼ同等であった。内腔側に $\mathrm{BaP}$ を添加したと ころ，BaP のほとんどすべてが Caco-2 膜通過時に 代謝され，代謝生成物は内腔側に逆輸送された。す なわち，本複合培養系では，代謝生成物が基底膜側 にはほとんぞ検出されなかったことから， Hep G2 に対する毒性は検出されなかった。このことから， $\mathrm{BaP}$ の毒性は小腸膜のバリアー効果のために実際 の曝露影響評価と比べて, 極めて低くなるものと推 察される. 最近の in vivo 研究においても, 小腸膜
障害時を除いて，BaP などの高脂質性の芳香族炭 化水素類に対する急性毒性が極めて低いことが示さ れており, ${ }^{21,22)}$ 本研究結果と符合する.

上述したように, 通常のマルチウェルプレート培 養器にて吸収過程を組み込んだ簡便複合培養評価系 は, in vivo 毒性評価系に近い応答を得ることが期 待される。また本評価系は, 実際の小腸膜のバリ ア一効果を実験的に再現できたことから, in vivo 吸収率の不明な化学種や, 環境試料や食品などの多 種多様な化学種を含むサンプルを, 一次スクリーニ ングできる簡便な評価系としても役立つものと考え られる。

\section{4. マイクロ化の限界は? 一最少必要細胞数の} 評価一

上述してきた in vitro 臟器モデルによる評価系で は, 既存の培養器を利用してきた。しかしながら, 限られた量のサンプルの計測や, 貴重かつ生体外で の増殖が不可能な細胞を用いることを想定すると， 将来はできる限り小型化されたデバイスやシステム の開発が望まれる。臓器に似た生理学的応答を得る デバイスを開発するには, 細胞が臓器として機能す るための必要な個数をデバイスに組み込む必要があ る. 近年, デバイスの小型化という観点から, 細胞 を用いたマイクロ流体デバイスやアレイチップなど の開発が盛んであるものの，それらに組み込む細胞 数の具体的な検討が行われていないのが実情であ る。例えば後者の細胞アレイチップでは，一度に大 量の情報を得たいというニーズから研究が進めら れ，様々な微細加工技術を利用してアレイチップを 作製しているものの, ${ }^{23-28)}$ その多くは細胞を単にラ イン状やドット状にアレイ化したのみである。そこ で筆者らは, 肝細胞を例に, チップ上に異なる個数 の肝細胞集団を形成させ，それぞれの細胞集団の機 能を調べることにより, 臟器に近い応答が得られる のに必要な最少細胞数を調べている.

まず，異なる細胞数を固定化したアレイチップを 作製するために，表面処理技術である光触媒リソグ ラフィー法29-31)を用いて, 基板表面に細胞を接着で きる異なる面積の微小領域を構築し，その微小領域 に細胞を固定化した. なお, 光触媒リソグラフィー 法とは, 光触媒である酸化于タンにフォトマスクを 介して紫外光を照射すると, 紫外光の照射された酸 化チタン表面からのみ活性酸素種が生成し, その活 


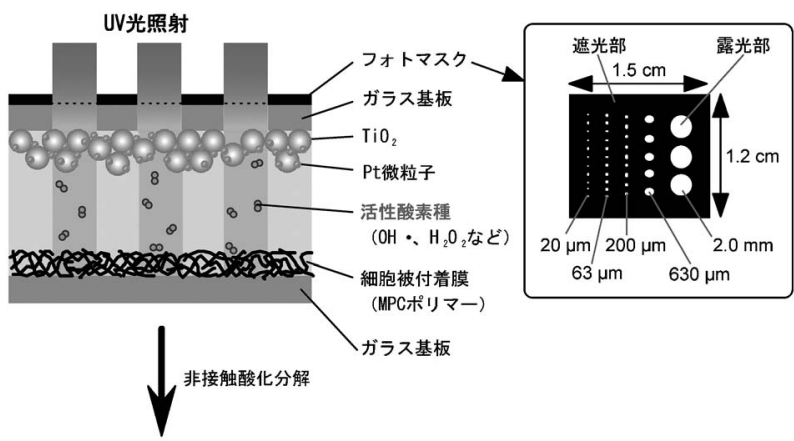

$\$ 2$
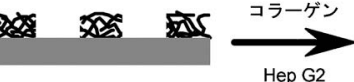

2......

Fig. 3. Experimental Setup for Photocatalytic Lithography Based on Remote Oxidation and Schematic Illustration of Glass Surface Arrayed with Hep G2 Cell

性酸素種が気相を拡散して離れた場所にある有機物 や無機物を酸化分解することによって，基板表面を パターニングする技術である（Fig. 3). Figure 3 に 示したフォトマスク（大日本印刷提供）を用いて, 細胞非付着性の 2-Methacryloyloxyethyl phosphorylcholine (MPC) ポリマー32,33)がコーティングし てあるガラス基板表面を光触媒リソグラフィー法で 処理し，酸化分解された領域にのみコラーゲンを吸 着させたのち，表面全体に， 3 章の複合評価系でも 用いた Hep G2 を播種したところ，フォトマスクと 同様の形状に細胞を固定化かつアレイ化できた。こ のとき，それぞれの微小領域には，細胞が 1 個から 約 10000 個，接着していた。

作製したチップを用いて，それぞれの細胞集団 の，肝機能の指標となるアルブミン分泌やシトクロ ム P 450 1A1/2（CYP 1A1/2）活性を，種々の免疫 染色法や蛍光標識法にて評価した。その結果，Hep G2 が約 1000 個以上の集団を形成したときに，約 100 個以下の集団と比べて，アルブミン分泌量及び CYP $1 \mathrm{~A} 1 / 2$ 活性の大幅な向上が観察された。また それらは，約 1000 個以上の細胞集団において，細 胞数当たりでほぼ一定值を示した。これは，約 1000 個以上集まった細胞集団では，隣り合う細胞 の接着に伴い，共有できる情報伝達物質が高濃度化 されたことや，オートクリンに効く Transforming Growth Factor（TGF）などのシグナル伝達物質が 局所的に高濃度に維持されたことで，アルブミン分 泌や CYP 1A1/2 などの肝機能に起因する転写因子 Hepatocyte Nuclear Factor（HNF-4）の発現が促進
されたものと推測される.インテグリンを介した細 胞外マトリックス（ECM）による情報伝達によっ て，HNF-4 の発現が促進されることも考えられる が，本実験系では，細胞集団を形成する個数に係わ らず，すべての細胞は ECM の 1 つである type I コ ラーゲン上で存在しており，細胞から分泌・蓄積さ れた ECM による HNF-4 発現の促進はほとんどな いものと推察される。（いずれにしても Hep G2 は, 少なくとも 1000 個以上で集団形成すると，肝臓に 近い機能を発現することが示唆された。この值は, 96 ウェルプレートの 1 ウェル当たりの細胞数と比 較すると，約 100 分の 1 に相当する．このことは, 96 ウェルの 1 ウェルを $1 / 100$ の細胞にしても同様 の応答が得られること，それ以下では生理学的応答 の取得は望めないことを示している。なお，Hep G2 はがん細胞としての側面を持つことから，それ ぞれの細胞集団での増殖活性を調べたところ，約 100 個以上の集団を形成したときに，細胞の増殖が 活発になることが確認された。この背景には， Conditioned Medium 効果が考えられる。10 個以下 の細胞集団が増殖するのに適切な培養液量を用いれ ば，TGF などによるオートクリン型シグナル伝達 により，Hep G2 細胞は増殖することが考えられ る. 一方 100 個以上の細胞集団では，その細胞集団 近傍で TGF などが高濃度に維持されるため, Conditioned Medium 効果に関係なく, 細胞増殖が活発 になったものと推察される．現在は，ラットの正常 肝細胞を用いて，チップ上に細胞数の異なる二次元 及び三次元で固定化したときのそれぞれの細胞集団 の肝機能評価を行っている. 特に，三次元で固定化 された場合での必要最少となる細胞数は，二次元の ものと比べてやや低くなることが期待される.

このように，少数の細胞をスポット・アレイ化す る細胞チップを作製する上では，同様の検討を行 い, 目的に応じて最少の必要十分な細胞数を決定し ておくことが必要であろう。また，細胞アレイチッ プに限らず，細胞を用いた小型のデバイスを構築す る場合，生理学的応答の取得を目標とするならば, それぞれの組織・臓器に応じて，デバイス内に導入 組織化する細胞数の検討を行っておく必要のあるこ とが示された。

5. おわりに

ここで紹介した 2 つ評価系，「肺上皮気液界面 
培養モデルとガス状物質曝露デバイス」と「小腸モ デルと標的臟器モデルの複合培養系」は，化学種に よってヒトが実際に曝露される状況を想定している ため, 従来の in vitro 評価系とは異なり，実際のヒ 卜個体への曝露プロセスや体内動態プロセスを考慮 した評価を行えるものと期待される。今まで開発し たこれらの評価系は，既存の培養器を用いたもので あるため, マイクロ化は試みてこなかった。 今後 は，「マイクロ化の限界は?」での検討を基に，個 体レベルでの動態プロセスを入れ込みながらも，よ り小型で使い易い評価デバイスを構築するというこ とが当面の目標になる，そのようなデバイスの究極 の姿は, 極限までマイクロ化した各蔵器モデルを, 血液循環を模倣した生理学的灌流回路で結合した 「オンチップヒューマン」であろう。これについて は, Shuler らのグループの精力的な研究があり, ${ }^{34}$ 筆者らの研究室でもより簡便なタイプのデバイスの 開発に着手している. ${ }^{35)}$

謝辞本稿で紹介した研究の一部は, 文部科学 省主要 5 分野リーディングプロジェクト「一般・産 業廃棄物・バイオマスの複合処理・再資源化」及び 「個体・ガス状試料の安全性評価システムの開発」 の援助により行われたものである.ここに深く御礼 申し上げる。

\section{REFERENCES}

1) Voisin C., Aerts C., Tonnel A. B., Houdret J. L., Ramon P., Pathol. Biol., 23, 453-459 (1975).

2) Furuyama A., Mochitate K., J. Cell Sci., 113, 859-868 (2000).

3) Sakai Y., Tomita K., Suzuki M., Ono Y., Sakoda A., AATEX, 11, 59-67 (2005).

4) Wright J. R., Wager R. E., Hawgood S., Dobbs L., Clements J. A., J. Biol. Chem., 262, 2888-2894 (1987).

5) Shen B. Q., Finkbeiner W. E., Wine J. J., Mrsny R. J., Widdicombe J. H., Am. J. Physiol., 266, L493-L501 (1994).

6) Knebel J. W., Ritter D., Aufderheide M., Toxicol. in Vitro, 16, 185-192 (2002).

7) Fujita S., "Dokuseigaku-Seitai, Kankyo, Seitaikei-," Asakura Publishing Co. Ltd., 1999 (Japanese text).
8) Takamura R., Sakai Y., PETROTECH, 28, 322-326 (2005) (Japanese text).

9) Komori K., Murai K., Fujii T., Ono Y., Sakai Y., Seisan Kenkyu, 59, 89-92 (2007) (Japanese text).

10) Shimizu K., Tomita K., Tsuru T., Sakai Y., Sakoda A., Kankyo Kagakukaishi, 15, 425431 (2002) (Japanese text).

11) Shimizu K., Tomita K., Sakai Y., Sakoda A., Biosci. Bioind., 61, 39-40 (2003) (Japanese text).

12) Shimizu K., Endo O., Goto S., Sakoda A., Ono Y., Sakai Y., Biochem. Eng. J., 22, 1-9 (2004).

13) Verheyen G. R., Nuijten J.-M., Hummelen P. V., Schoeters G. R., Toxicol. in Vitro, 18, 377 (2004).

14) Siegel P. D., Saxena R. K., Saxena Q. B., Ma J. K. H., Ma J. Y. C., Yin X.-J., Castranova V., Al-Humadi N., Lewis D. M., J. Toxicol. Environ. Health, Part A, 67, 221-231 (2004).

15) Yoshida S., Sagai M., Oshio S., Umeda T., Ihara T., Sugamata M., Sugawara I., Takeda K., Int. J. Androl., 22, 307-315 (1999) .

16) Ichinose T., Furuyama A., Sagai M., Toxicology., 99, 153-167 (1995).

17) Sakai Y., Arai T., Sakoda A., Suzuki M., $A A$ TEX, 7, 47-58 (2001).

18) Autursson P., Karlsson J., Biochem. Biophys. Res. Commun., 175, 880-885 (1991).

19) Gan L. S., Moseley M. A., Khosla B., Augastijns P. F., Bradshaw T. P., Hendren R. W., Thakker D. R., Drug Metab. Dispos., 24, 344-349 (1996).

20) Choi S.-H., Nishikawa M., Sakoda A., Sakai Y., Toxicol. in Vitro, 18, 393-402 (2004).

21) Foth H., Kahl R., Kahl G. F., Food Chem. Toxicol., 26, 45-51 (1988).

22) Ramesh A., Inyang F., Hood D. B., Archibong A. E., Knuckles M. E., Nyanda A. M., Exp. Toxicol. Pathol., 53, 275-290 (2001).

23) Stenger D. A., Georger J. H., Dulcey C. S., Hickman J. J., Rudolph A. S., Nielsen T. B., McCort S. M., Calvert J. M., J. Am. Chem. Soc., 114, 8435-8442 (1992).

24） Kane R. S., Takayama S., Otsuni E., Inger D. E., Whitesides G. M., Biomaterials, 20, 23632376 (1999). 
25) Kaji H., Kanada M., Oyamatsu D., Matsue T., Nishizawa M., Langmuir, 20, 16-19 (2004).

26) Nakanishi J., Kikuchi Y., Takarada T., Nakayama H., Yamaguchi K., Maeda M., J. Am. Chem. Soc., 126, 16324-16325 (2004).

27) Edahiro J., Sumaru K., Tada Y., Ohi K., Takagi T., Kameda M., Shinbo T., Kanamori T., Yoshimi Y., Biomacromolecules, 6, 970974 (2005).

28) Nakamura M., Kobayashi A., Takagi F., Watanabe A., Hiruma Y., Ohuchi K., Iwasaki Y., Horie M., Morita I., Takatani S., Tissue Eng., 11, 1658-1666 (2005).

29) Tatsuma T., Kubo W., Fujishima A., Langmuir, 18, 9632-9634 (2002).
30) Kubo W., Tatsuma T., Fujishima A., Kobayashi H., J. Phys. Chem. B, 108, 30043009 (2004).

31) Kubo W., Tatsuma T., J. Mater. Chem., 15, 3104-3108 (2005).

32) Ishihara K., Oshida H., Endo Y., Ueda T., Watanabe A., Nakabayashi N., J. Biomed. Mater. Res., 26, 1543-1552 (1992).

33) Ishihara K., Nomura H., Mihara T., Kurita K., Iwasaki Y., Nakabayashi N., J. Biomed. Mater. Res., 39, 323-330 (1998).

34) Shuler M. L., Ghanem A., Quick D., Wong M. C., Miller P., Biotechnol. Bioeng . , 52, 45 -60 (1996).

35) Nakayama H., Kimura H., Komori K., Fujii T., Sakai Y., J. Robotics Mech. (in press). 